Marina de Oliveira Fernandez

\title{
Diversidade de hidroides (Cnidaria) do Atlântico profundo sob uma perspectiva macroecológica
}

Diversity of deep-sea Atlantic hydroids (Cnidaria) under a macroecological perspective 


\section{Resumo}

A variação batimétrica nos oceanos e suas mudanças ambientais associadas impõem limites à distribuição de espécies, modulando a ocorrência de indivíduos com diferentes formas, funções e histórias de vida de acordo com a profundidade, e sendo, portanto, importante para o entendimento de padrões da biodiversidade marinha. Este estudo objetiva inferir padrões de distribuição de hidroides no Oceano Atlântico e mares árticos e antárticos adjacentes a mais de $50 \mathrm{~m}$ de profundidade, buscando contribuir para o entendimento da diversificação e estruturação associadas à variação batimétrica que propiciaram a ocupação dos diferentes ambientes pelo grupo. Apresentamos pela primeira vez inferências das amplitudes de distribuição batimétrica das espécies, da variação de características funcionais de indivíduos e espécies com a profundidade e da distribuição da composição de espécies ao longo da profundidade e da latitude. Em conjunto, os resultados indicam que a distribuição de hidroides no Atlântico profundo está relacionada a fatores históricos e a gradientes ambientais associados às variações latitudinal e batimétrica. Os tamanhos reduzidos e a baixa fertilidade em mar profundo sugerem que a colonização e a evolução de hidroides ao longo da profundidade são principalmente influenciadas pela disponibilidade de alimento e pelas baixas densidades populacionais. Ainda, a maior proporção de espécies e indivíduos solitários em mar profundo e o maior uso de substratos não-consolidados sugerem influência da disponibilidade de substrato. A proporção de espécies capazes de liberar medusas abaixo de $50 \mathrm{~m}$ é geralmente menor que em águas rasas costeiras, mas a proporção aumenta com a profundidade, principalmente abaixo de $1.500 \mathrm{~m}$. A liberação de medusas seria desvantajosa em um ambiente com baixas densidades populacionais, por aumentar a incerteza da fecundação dada pela dispersão de gametas, e despender mais energia para reprodução em um cenário de poucos recursos alimentares. Amplas distribuições batimétricas sugerem capacidade de dispersão vertical e alta tolerância às mudanças ambientais associadas à variação batimétrica. Os resultados indicam também que a colonização de hidroides em mar profundo ocorre em um sistema de fonte-sumidouro, no qual as populações de mar profundo seriam sustentadas por imigração de águas mais rasas. Mostramos neste estudo que hidroides são importantes habitantes do mar profundo e que o entendimento da diversidade do grupo neste ambiente se beneficiará de investigações em áreas ainda pouco amostradas, como latitudes tropicais sul e profundidades abaixo de $1.000 \mathrm{~m}$.

Palavras-chave: Macroecologia marinha, mar profundo, Hydrozoa 


\section{Abstract}

The bathymetric variation in the oceans and associated environmental changes impose limits on the distribution of species, modulating the occurrence of individuals with different forms, functions and life histories according to depth, and is therefore important for the understanding of marine biodiversity patterns. This study aims to infer patterns of hydroid distribution in the Atlantic Ocean and adjacent Arctic and Antarctic seas at more than $50 \mathrm{~m}$ deep, seeking to contribute to the understanding of the diversification and structuring associated with the bathymetric variation that favored the occupation of the different environments by the group. We present for the first time inferences on the bathymetric ranges of distribution of the species, on the variation of functional traits of individuals and species with depth, and on the distribution of the species composition along depth and latitude. Together, the results indicate that the distribution of hydroids in the deep Atlantic is related to historical factors and to the environmental gradients associated with latitudinal and bathymetric variations. Reduced sizes and low fertility in deep sea suggest that colonization and evolution of hydroids along depth are mainly influenced by food availability and low population densities. Also, the greater proportion of solitary species and individuals in the deep sea and the greater use of unconsolidated substrates suggest influence of substrate availability. The proportion of species capable of releasing medusae below $50 \mathrm{~m}$ deep is generally lower than in shallow coastal waters, but the proportion increases with depth, especially below 1,500 m. The release of medusae would be disadvantageous in an environment with low population densities, by increasing the uncertainty of fertilization given by the dispersion of gametes, and expending more energy for reproduction in a scenario of few food resources. Wide bathymetric distributions suggest vertical dispersal capacity and high tolerance to the environmental changes associated to the bathymetric variation. The results also indicate that colonization of hydroids in the deep sea occurs in a source-sink system in which deep-sea populations would be sustained by shallower water immigration. We show in this study that hydroids are important inhabitants of the deep sea and that the understanding of the diversity of the group in this environment will benefit from investigations in areas still poorly sampled, such as southern tropical latitudes and depths below 1,000 m.

Keywords: Marine macroecology, deep sea, Hydrozoa 


\section{Introdução Geral}

A macroecologia estuda a relação dos organismos com o ambiente onde vivem em grandes escalas espaciais, a partir da caracterização de padrões de distribuição da diversidade, como riqueza, abundância, amplitudes de distribuição ou tamanhos corporais (Brown \& Maurer, 1989; Brown, 1995; Gaston \& Blackburn, 2000; Witman \& Roy, 2009; Keith et al., 2012). A distribuição atual da diversidade decorre de eventos históricos de origens, expansões, diversificações e extinções das espécies, e relaciona-se à capacidade de seus indivíduos e populações ocuparem diferentes nichos (Valentine, 1973; Jablonski et al., 1985, 2006; Sexton et al., 2009; Lomolino et al., 2017). Características funcionais dos organismos (= “traits" em inglês) estão relacionadas a suas respostas a fatores bióticos ou abióticos, afetando suas capacidades de crescimento, sobrevivência e reprodução em habitats distintos, assim influenciando diretamente a variação espacial na composição de espécies e podendo contribuir com o entendimento da seleção natural e do funcionamento de ecossistemas (Soininen et al., 2007; Violle et al., 2007; Bremner, 2008; Connell \& Irving, 2009; Webb et al., 2009; Brun et al., 2016).

A variação batimétrica nos oceanos, com seus gradientes e mudanças ambientais associados, como queda de temperatura, luminosidade, disponibilidade de matéria orgânica e de substratos consolidados, e aumento da pressão hidrostática, impõem limites à distribuição de espécies (Somero, 1990, 1992; Smith et al., 1997; McClain \& Hardy, 2010; Rex \& Etter, 2010; Brown \& Thatje, 2011; Talley et al., 2011; Jamieson, 2015), levando à ocorrência de indivíduos com diferentes formas, funções e histórias de vida de acordo com a profundidade (McClain, 2004; McClain et al, 2005; Rex et al., 2006; Ramirez-Llodra et al., 2010). Por outro lado, o aumento da profundidade leva a condições ambientais mais homogêneas, reduzindo barreiras ao fluxo gênico e levando a uma maior uniformidade da fauna (McClain \& Hardy, 2010; Rex \& Etter, 2010). A variação ambiental no fluxo de matéria orgânica particulada para o bentos profundo é considerada um fator importante influenciando mudanças faunais ao longo da profundidade, e estruturando as comunidades em mar profundo (Carney, 2005; Rex \& Etter, 2010; Wei et al., 2010; McClain et al., 2012; McClain \& Rex, 2015; Woolley et al., 2016).

Hidroides, os estágios polipoides, geralmente bentônicos, das espécies de Hydroidolina (exceto Siphonophorae) (Cornelius, 1995; Cartwright et al., 2008; Schuchert, 2012), são ecologicamente diversos e apresentam grande variação intra e interespecífica de formas e tamanhos nos diferentes ambientes (Gili \& Hughes, 1995; Cunha et al., 2016). Vivem desde 
águas rasas até profundidades hadais (Kramp, 1956; Calder, 1996; 1998), alimentando-se de matéria em suspensão e usando seus nematocistos para capturar pequenos organismos planctônicos (Gili \& Hughes, 1995). Geralmente colonizam substratos consolidados, mas também ocorrem em substratos não-consolidados (Gili \& Hughes, 1995; Bouillon et al., 2006; Schuchert, 2012). Reproduzem-se sexuada e assexuadamente (Gili \& Hughes, 1995). Suas espécies podem ou não liberar medusas ao longo dos ciclos de vida. Arquetipicamente, pólipos brotam medusas dioicas, portadoras dos gametas que, após fertilizados, desenvolvem-se em larvas plânulas, as quais se metamorfoseiam novamente em pólipos bentônicos (Cornelius, 1995). Há, porém, diferentes níveis de redução da fase de medusa nas diferentes linhagens, até sua completa supressão em $\sim 74 \%$ das espécies (Gibbons et al., 2010), nas quais o pólipo porta os gametas em gonóforos fixos.

Os primeiros registros de hidroides em profundidades maiores do Atlântico foram obtidos por expedições do final do século XIX, a partir da coleta de novas espécies e também estendendo as amplitudes de distribuição de espécies de áreas mais rasas (e.g., Allman, 1874; Smith \& Harger, 1874; Verrill, 1874). No entanto, apesar da importância de compreender os efeitos da variação batimétrica na distribuição da biodiversidade marinha, há apenas inferências pontuais ou regionais da distribuição de hidroides de mares profundos, e com diferentes focos (e.g., Calder, 1998; Henry et al., 2008). Na realidade, o conhecimento atual sobre os padrões de distribuição no mar profundo é escasso para a maioria dos táxons de invertebrados marinhos, com poucas sínteses do conhecimento de táxons superiores em oceanos como um todo (Allen \& Sander, 1996; Rex et al., 1993, 2000, 2005, 2006; Rex \& Etter, 2010; Woolley et al., 2016).

\section{Objetivo Geral}

Este estudo tem o objetivo de inferir padrões de distribuição de hidroides no Oceano Atlântico e mares árticos e antárticos adjacentes com mais de $50 \mathrm{~m}$ de profundidade, melhorando nossa compreensão da diversificação e estruturação associadas à batimetria que propiciaram a ocupação dos diferentes ambientes pelo grupo.

\section{Organização da Tese}

À parte esta introdução geral, essa tese é apresentada em 4 capítulos principais e uma seção de considerações finais. 
O Capítulo 1 apresenta um extenso levantamento bibliográfico de registros de hidroides, em toda a área estudada, com o objetivo de descrever a distribuição batimétrica das espécies. Investigamos as relações das amplitudes de distribuição batimétrica com as regiões, latitudes e profundidades médias de ocorrência, assim como com a taxonomia do grupo. Por fim, examinamos a influência de fatores históricos nos padrões de profundidades de ocorrência sob um contexto filogenético.

O Capítulo 2 caracteriza a distribuição de uma série de características funcionais das espécies (= "traits") e indivíduos de hidroides ao longo da profundidade, contrastando-as com o conhecimento sobre a biologia do grupo e a ecologia de mar profundo.

No Capítulo 3 inferimos padrões de distribuição das espécies de hidroides em todo o Oceano Atlântico e mares polares circundantes considerando a variação batimétrica e latitudinal, buscando reconhecer limites e gradientes de distribuição.

O Capítulo 4 é um artigo publicado em resposta a Chaudhary et al. (2016), abordando a complexidade dos padrões de distribuição de espécies e o viés gerado pela heterogeneidade amostral nos dois hemisférios. 


\section{Considerações Finais}

Este estudo é pioneiro nas inferências de padrões de distribuição da diversidade de hidroides no Oceano Atlântico e mares polares circundantes em relação às variações batimétrica e latitudinal. Foram estudadas as amplitudes de distribuição batimétrica das espécies (Capítulo 1), a variação de características funcionais de indivíduos e espécies com a profundidade (Capítulo 2), e a distribuição da composição de espécies ao longo da profundidade e da latitude (Capítulo 3). Os padrões indicam que a distribuição de hidroides no Atlântico profundo é mediada tanto por fatores históricos - conforme sugerido pelo isolamento da fauna Patagônica e Antártica e pelas diferenças em amplitudes de distribuição batimétrica entre táxons e regiões -, quanto por gradientes ambientais associados à variação latitudinal e batimétrica. Tamanhos reduzidos e baixa fertilidade em mar profundo sugerem que a colonização e a evolução de hidroides ao longo da profundidade são principalmente influenciadas pela disponibilidade de alimento e pelas baixas densidades populacionais, enquanto a maior proporção de espécies com indivíduos solitários em mar profundo e maior uso de substratos não-consolidados também por formas coloniais sugerem influência da disponibilidade de substrato (Ramirez-Llodra et al., 2010).

As amplas distribuições batimétricas e a tendência de maior uniformidade da fauna abaixo de $1.000 \mathrm{~m}$ de profundidade devem ser causadas pela grande capacidade de dispersão vertical e horizontal, assim como certamente inclui a tolerância às mudanças ambientais associadas à variação batimétrica (Young et al., 1997a, 1997b). Da mesma forma, maiores amplitudes de distribuição geográfica para espécies com maiores amplitudes de distribuição batimétrica também devem resultar de tolerâncias fisiológicas e capacidades dispersivas.

Os dados sugerem que a colonização de hidroides no Atlântico profundo ocorre em um sistema de fonte-sumidouro, no qual as populações de profundidade seriam sustentadas pela imigração de indivíduos de águas mais rasas (Rex et al., 2005). As extensões das amplitudes de distribuição das espécies, geralmente do raso para o fundo, com raras espécies estritamente batiais ou abissais, e a menor proporção de espécies férteis abaixo de $1.000 \mathrm{~m}$ de profundidade, apontam para taxas mais baixas de reprodução sexuada em estratos batimétricos profundos. Ainda, a proporção de espécies capazes de liberar medusa abaixo de $50 \mathrm{~m}$ é geralmente mais baixa do que em águas rasas costeiras - apesar de a proporção aumentar com a profundidade, principalmente abaixo de $1500 \mathrm{~m}$. A liberação de medusa seria desvantajosa em um ambiente com baixas densidades populacionais, por diminuir a chance de fecundação devido ao aumento 
da dispersão de gametas, e ainda despender mais energia para reprodução em um ambiente com poucos recursos energéticos. No entanto, apesar do aumento de grupos meroplanctônicos com o aumento da profundidade, seus baixos índices de fertilidade adicionam evidências para a hipótese de fonte-sumidouro (Rex et al., 2005).

Algo importante deste estudo é que lidamos com um esforço amostral desigual ao longo do Oceano Atlântico, menor em latitudes tropicais sul e em profundidades abaixo de $1.000 \mathrm{~m}$. Dados estão disponíveis principalmente próximos às margens continentais, com um hiato no conhecimento nas extensas planícies abissais. Isso demonstra a necessidade de melhores amostragens no futuro. O maior número de registros profundos nas latitudes mais bem amostradas é a base para afirmar que há subestimativa de riqueza de dados biológicos associados para diversas áreas - ou pior, nenhuma área está, de fato, adequadamente amostrada. A alta diversidade que já é conhecida para o grupo em mar profundo pode revelar-se ainda maior com futuras coletas direcionadas às áreas menos estudadas e a diferentes habitats, como por exemplo os de substratos não-consolidados, que tem grande potencial de riqueza.

O caminho a seguir para o estudo de macroecologia de hidroides de mar profundo inclui maximizar o rendimento dos dados já coletados e um maior apoio e dedicação à amostragem de áreas profundas, principalmente do Atlântico Sul. Derivando diretamente desta tese, é de particular interesse um estudo que relacione as características funcionais de hidroides tanto com as amplitudes de distribuição batimétrica quanto com as variações latitudinais e batimétricas de composição de espécies, com o objetivo de revelar a influência de características funcionais, principalmente relacionadas ao tamanho e reprodução, na distribuição de espécies. Por fim, investigações futuras integrando variáveis ambientais e filogenias devem contribuir com o entendimento dos processos micro e macroevolutivos envolvidos nos padrões aqui observados (Leclère et al., 2007; Cartwright \& Nawrocki, 2010; Fine, 2015). 


\section{Referências}

Allen, J.A. \& H.L. Sanders. 1996. The zoogeography, diversity and origin of the deep-sea protobranch bivalves of the Atlantic: The epilogue. Progress in Oceanography 38: 95153.

Allman, G.J. 1874. Report on the Hydroida collected during the expedition of H.M.S. "Porcupine". Transaction of the Zoological Society 8: 469-481.

Allman, G.J. 1888. Report on the Hydroida dredged by H.M.S. Challenger during the years 1873-76. Part II. The Tubularinae, Corymorphinae, Campanularinae, Sertularinae, and Thalamophora. Report on the Scientific Results of the Voyage of H.M.S. Challenger During the Years 1873-76. Zoology 23: 1-90.

Altuna, A. 2007. Bathymetric distribution patterns and biodiversity of benthic Medusozoa (Cnidaria) in the Bay of Biscay (north-eastern Atlantic). Journal of the Marine Biological Association of the United Kingdom 87: 681-694.

Anderson, J.B.; S.S. Shipp; A.L. Lowe; J.S. Wellner \& A.B. Mosola. 2002. The Antarctic ice sheet during the Last Glacial Maximum and its subsequent retreat history: a review. Quaternary Science Reviews 21: 49-70.

Anderson, M.J. 2001. A new method for non-parametric multivariate analysis of variance. Austral Ecology 26: 32-46.

Anderson, M.J.; R.N. Gorley \& K.R. Clarke. 2008. PERMANOVA+ for PRIMER: Guide to Software and Statistical Methods. PRIMER-E, Plymouth.

Angilletta, M.J. \& A.E. Dunham. 2003. The temperature-size rule in ectotherms: simple evolutionary explanations may not be general. The American Naturalist 162: 332-342.

Angilletta, M.J.; T.D. Steury \& M.W. Sears. 2004. Temperature, growth rate, and body size in ectotherms: fitting pieces of a life-history puzzle. Integrative \& Comparative Biology 44: 498-509.

Ansín Agís J.; F. Ramil \& W. Vervoort. 2001. Atlantic Leptolida (Hydrozoa, Cnidaria) of the families Aglaopheniidae, Halopterididae, Kirchenpaueriidae and Plumulariidae collected during the CANCAP and Mauritania-II expeditions of the National Museum of Natural History, Leiden, the Netherlands. Zoologische Verhandelingen, Leiden 333: $1-268$. 
Antsulevich, A.E. 2015. Biogeographic and faunistic division of the Eurasian Polar Ocean based on distributions of Hydrozoa (Cnidaria). Journal of the Marine Biological Association of the United Kingdom 95: 1533-1539.

Baco, A.R.; R.J. Etter; P.A. Ribeiro; S. von der Heyden; P. Beerli \& B.P. Kinlan. 2016. A synthesis of genetic connectivity in deep-sea fauna and implications for marine reserve design. Molecular Ecology 25: 3276-3298.

Beauchard, O.; H. Veríssimo; A.M. Queirós \& P.M.J. Herman. 2017. The use of multiple biological traits in marine community ecology and its potential in ecological indicator development. Ecological Indicators 76: 81-96.

Beedessee, G.; H. Watanabe; T. Ogura; S. Nemoto; T. Yahagi; S. Nakagawa; K. Nakamura; K. Takai; M. Koonjul; D.E.P. Marie. 2013. High connectivity of animal populations in deep-sea hydrothermal vent fields in the central Indian ridge relevant to its geological setting. PLoS ONE 8: e81570.

Benitez Villalobos, F.; P.A. Tyler \& C.M. Young. 2006. Temperature and pressure tolerance of embryos and larvae of the Atlantic seastars Asterias rubens and Marthasterias glacialis (Echinodermata: Asteroidea): potential for deep-sea invasion. Marine Ecology Progress Series 314: 109-117.

Bennett, B.A.; C.R. Smith; B. Glaser \& H.L. Maybaum. 1994. Faunal community structure of a chemoautotrophic assemblage on whale bones in the deep northeast Pacific Ocean. Marine Ecology Progress Series 108: 205-223.

Benson, R.H. 1975. The origin of the psychrosphere as recorded in changes of deep-sea ostracode assemblages. Lethaia 8: 69-83.

Berrill, N.J. 1950. Growth and form in calyptoblastic hydroids. II. Polymorphism within the Campanularidae. Journal of Morphology 87: 1-26.

Blanco, R; M.A. Shields; A.J. Jamieson. 2013. Macrofouling of deep-sea instrumentation after three years at $3690 \mathrm{~m}$ depth in the Charlie Gibbs fracture zone, mid-Atlantic ridge, with emphasis on hydroids (Cnidaria: Hydrozoa). Deep-Sea Research II 98: 370-373.

Boero, F. 1984. The ecology of marine hydroids and effects of environmental factors: a review. P.S.Z.N.I.: Marine Ecology 5: 93-118.

Boero, F. \& J. Bouillon. 1989. An evolutionary interpretation of anomalous medusoid stages in the life cycles of some Leptomedusae (Cnidaria). pp. 37-41. In: J.S. Ryland \& P.A. Tyler (Eds). Reproduction, Genetics and Distributions of Marine Organisms: 23rd European Marine Biology Symposium, School of Biological Sciences, University of Wales, Swansea. 
Bolam, S.G.; C. Garcia; J. Eggleton; A.J. Kenny; L. Buhl-Mortensen; G. Gonzalez-Mirelis; T. van Kooten; G. Dinesen; J. Hansen; J.G. Hiddink; M. Sciberras; C. Smith; N. Papadopoulou; A. Gumus; G. Van Hoey; O.R. Eigaard; F. Bastardie \& A.D. Rijnsdorp. 2017. Marine Environmental Research 126: 1-13.

Bonnin, J.; H.V. Haren; P. Hosegood \& G.J.A. Brummer. 2006. Burst resuspension of seabed material at the foot of the continental slope in the Rockall Channel. Marine Geology 226: $167-184$.

Bosch, T.C.G.; M. Adamska; R. Augustin; T. Domazet-Loso; S. Foret; S. Fraune; N. Funayama; J. Grasis; M. Hamada; M. Hatta; B. Hobmayer; K. Kawai; A. Klimovich; M. Manuel; C. Shinzato; U. Technau; S. Yum \& D.J. Miller. 2014. How do environmental factors influence life cycles and development? An experimental framework for early-diverging metazoans. Bioessays 36: 1185-1194.

Bouillon, J.; C. Gravili; F. Pagès; J.M. Gili \& F. Boero. 2006. An introduction to Hydrozoa. Publications Scientifique du Muséum, Paris.

Braendle, C.; A. Heyland \& T. Flatt. 2011. Integrating mechanistic and evolutionary analysis of life history variation. pp. 3-10. In: T. Flatt \& A. Heyland (Eds). Mechanisms of life history evolution. The genetics and physiology of life history traits and trade-offs. Oxford University Press, New York.

Brandt, A. 1992. Origin of antarctic Isopoda (Crustacea, Malacostraca). Marine Biology 113: 415-423.

Brandt, A.; A.J. Gooday; S.N. Brandão; S. Brix; W. Brökeland; T. Cedhagen; M. Choudhury; N. Cornelius; B. Danis; I. De Mesel; R.J. Diaz; D.C. Gillan; B. Ebbe; J.A. Howe; D. Janussen; S. Kaiser; K. Linse; M. Malyutina; J. Pawlowski; M. Raupach \& A. Vanreusel. 2007a. First insights into the biodiversity and biogeography of the Southern Ocean deep sea. Nature 447: 307-311.

Brandt, A.; C. De Broyer; A.J. Gooday; B. Hilbig \& M.R.A. Thomson. 2004. Introduction to ANDEEP (ANtarctic benthic DEEP-sea biodiversity: colonization history and recent community patterns) - a tribute to Howard L. Sanders. Deep-Sea Research II 51: 14571465.

Brandt, A.; C. De Broyer; I. De Mesel; K.E. Ellingsen; A.J. Gooday; B. Hilbig; K. Linse; M.R.A. Thomson \& P.A. Tyler. 2007b. The biodiversity of the deep Southern Ocean benthos. Philosophical Transactions of the Royal Society B 362: 39-66. 
Brayard, A.; G. Escarguel \& H. Bucher. 2005. Latitudinal gradient of taxonomic richness: combined outcome of temperature and geographic mid-domains effects? Journal of Zoological Systematics and Evolutionary Research 43: 178-188.

Bremner, J. 2008. Species' traits and ecological functioning in marine conservation and management. Journal of Experimental Marine Biology and Ecology 366: 37-47.

Bremner, J.; S.I. Rogers \& C.L.J. Frid. 2006a. Matching biological traits to environmental conditions in marine benthic ecosystems. Journal of Marine Systems 60: $302-316$.

Bremner, J.; S.I. Rogers \& C.L.J. Frid. 2006b. Methods for describing ecological functioning of marine benthic assemblages using biological traits analysis (BTA). Ecological Indicators 6: $609-622$.

Brey, T.; C. Dahm; M. Gorny; M. Klages; M. Stiller \& W.E. Arntz. 1996. Do Antarctic benthic invertebrates show an extended level of eurybathy? Antarctic Science 8: 3-6.

Brown, A. \& S. Thatje. 2011. Respiratory response of the deep-sea amphipod Stephonyx biscayensis indicates bathymetric range limitation by temperature and hydrostatic pressure. PLoS ONE 6: e28562.

Brown, J.H. 1995. Macroecology. The University of Chicago Press, Chicago.

Brown, J.H. \& B.A. Maurer. 1989. Macroecology: the division of food and space among species on continents. Science 243: 1145-1150.

Brown, J.H.; J.F. Gillooly; A.P. Allen; V.M. Savage \& G.B. West. 2004. Toward a metabolic theory of ecology. Ecology 85: 1771-1789.

Brun, P.; M.R. Payne \& T. Kiørboe. 2016. Trait biogeography of marine copepods - an analysis across scales. Ecology Letters 19: 1403-1413.

Calder, D.R. 1992. Similarity analysis of hydroid assemblages along a latitudinal gradient in the western North Atlantic. Canadian Journal of Zoology 70: 1078-1085.

Calder, D.R. 1996. Hydroids (Cnidaria: Hydrozoa) recorded from depths exceeding $3000 \mathrm{~m}$ in the abyssal western North Atlantic. Canadian Journal of Zoology 74: 1721-1726.

Calder, D.R. 1998. Hydroid diversity and species composition along a gradient from shallow waters to deep sea around Bermuda. Deep-Sea Research I 45: 1843-1860.

Calder, D.R. 2000. Assemblages of hydroids (Cnidaria) from three seamounts near Bermuda in the western North Atlantic. Deep-Sea Research I 47: 1125-1139.

Calder, D.R. 2017. Additions to the hydroids (Cnidaria, Hydrozoa) of the Bay of Fundy, northeastern North America, with a checklist of species reported from the region. Zootaxa 4256: 1-86. 
Calder, D.R. \& W. Vervoort. 1998. Some hydroids (Cnidaria: Hydrozoa) from the Mid-Atlantic Ridge, in the North Atlantic Ocean. Zoologische Verhandelingen 319: 1-65.

Carney, R.S. 2005. Zonation of deep biota on continental margins. Oceanography and Marine Biology: An Annual Review 43: 211-278.

Carré, D. \& C. Carré. 2000. Origin of germ cells, sex determination, and sex inversion in medusae of the genus Clytia (Hydrozoa, Leptomedusae): the influence of temperature. Journal of Experimental Zoology 287: 233-242.

Cartwright, P. \& A.M. Nawrocki. 2010. Character evolution in Hydrozoa (phylum Cnidaria). Integrative and Comparative Biology 50: 456-472.

Cartwright, P.; N.M. Evans; C.W. Dunn; A.C. Marques; M.P. Miglietta; P. Schuchert \& A.G. Collins. 2008. Phylogenetics of Hydroidolina (Hydrozoa: Cnidaria). Journal of the Marine Biological Association of the United Kingdom 88: 1663-1672.

Casares, B.M.; J.J. Soto Àngel \& A.L. Peña Cantero. 2017. Towards a better understanding of Southern Ocean biogeography: new evidence from benthic hydroids. Polar Biology In Press: $1-14$.

Chapelle, G. \& L.S. Peck. 1999. Polar gigantism dictated by oxygen availability. Nature 399: $114-115$.

Chaudhary, C.; H. Saeedi \& M.J. Costello. 2016. Bimodality of latitudinal gradients in marine species richness. Trends in Ecology \& Evolution 31: 670-676.

Chaudhary, C.; H. Saeedi \& M.J. Costello. 2017. Marine species richness is bimodal with latitude: a reply to Fernandez \& Marques 32: 234-237.

Childress, J.J.; D.L. Cowles; J.A. Favuzzi \& T.J. Mickel. 1990. Metabolic rates of benthic deepsea decapod crustaceans decline with increasing depth primarily due to the decline in temperature. Deep-Sea Research 37: 929-949.

Clark, M.R.; M. Consalvey \& A.A. Rowden. 2016. Biological sampling in the deep sea. WileyBlackwell.

Clarke, A. 1996. The distribution of antarctic marine benthic communities. Foundations for Ecological Research West of the Antarctic Peninsula, Antarctic Research Series 70: 219-230.

Clarke, A. 2003. The polar deep seas. pp. 239-260. In: Ecosystems of the Deep Oceans. P.A. Tyler (Ed). Ecosystems of the World vol. 28, Elsevier Science, Amsterdam.

Clarke, A.; D.K.A. Barnes \& D.A. Hodgson. 2005. How isolated is Antarctica? Trends in Ecology and Evolution 20: 1-3. 
Clarke, A. \& J.A. Crame. 1989. The origin of the Southern Ocean marine fauna. pp. 253-268. In: Origins and evolution of the Antarctic biota. J.A. Crame (Ed). Geological Society Special Publications vol. 47, The Geological Society, London.

Clarke, A.; R.B. Aronson; J.A. Crame; J.-M. Gili \& D.B. Blake. 2004. Evolution and diversity of the benthic fauna of the Southern Ocean continental shelf. Antarctic Science 16: 559568.

Clarke, K.R. \& R.M. Warwick. 2001. Change in marine communities: an approach to statistical analysis and interpretation, 2nd ed. PRIMER-E, Plymouth.

Clarke, K.R. \& R.N. Gorley. 2006. PRIMER v6: User Manual/Tutorial. PRIMER-E, Plymouth.

Collins, A.G. 2000. Towards understanding the phylogenetic history of Hydrozoa: hypothesis testing with 18S gene sequence data. Scientia Marina 64: 5-22.

Collins, A.G.; P. Schuchert; A.C. Marques; T. Jankowski; M. Medina and B. Schierwater. 2006. Medusozoan phylogeny and character evolution clarified by new large and small subunit rDNA data and an assessment of the utility of phylogenetic mixture models. Systematic Biology 55: 97-115.

Comita, L.S. 2017. How latitude affects biotic interactions. Science 356: 1328-1329.

Connell, S.D. \& A.D. Irving. 2009. The subtidal ecology of rocky coasts: local-regionalbiogeographic patterns and their experimental analysis. pp. 392-417. In: Witman, J.D. \& K. Roy (Eds) Marine macroecology. The University of Chicago Press, Chicago.

Cornelius, P.F.S. 1979. A revision of the species of Sertulariidae (Coelenterata: Hydroida) recorded from Britain and nearby seas. Bulletin of the British Museum (Natural History), Zoology 34: 243-321.

Cornelius, P.F.S. 1992. Medusa loss in leptolid Hydrozoa (Cnidaria), hydroid rafting, and abbreviated life-cycles among their remote-island faunae: an interim review. Scientia Marina 56: 245-261.

Cornelius, P.F.S. 1995. North-west European Thecate hydroids and their medusae. v. 50 (Part 1,2). The Linnean Society of London and the Estuarine and Coastal Sciences Association.

Coro, G.; C. Magliozzi; A. Ellenbroek; K. Kaschner \& P. Pagano. 2016. Automatic classification of climate change effects on marine species distributions in 2050 using the AquaMaps model. Environmental and Ecological Statistics 23: 155-180.

Costello, M.J. \& C. Chaudhary. 2017. Marine biodiversity, biogeography, deep-sea gradients, and conservation. Current Biology 27: R511-R527. 
Courtene-Jones, W.; B. Quinn; S.F. Gary \& A.O.M. Mogg. 2017. Microplastic pollution identified in deep-sea water and ingested by benthic invertebrates in the Rockall Trough, North Atlantic Ocean. Environmental Pollution 231: 271-280.

Crowell, S. 1957. Differential responses of growth zones to nutritive level, age and temperature in the colonial hydroid Campanularia. Journal of Experimental Zoology 134: 63-90.

Cunha, A.F.; A.G. Collins \& A.C. Marques. 2017. Phylogenetic relationships of Proboscoida Broch, 1910 (Cnidaria, Hydrozoa): Are traditional morphological diagnostic characters relevant for the delimitation of lineages at the species, genus, and family levels? Molecular Phylogenetics and Evolution 106: 118-135.

Cunha, A.F.; G.N. Genzano \& A.C. Marques. 2015. Reassessment of morphological diagnostic characters and species boundaries requires taxonomical changes for the genus Orthopyxis L. Agassiz, 1862 (Campanulariidae, Hydrozoa) and some related campanulariids. PLoS ONE 10: e0117553.

Cunha, A.F.; M.M. Maronna \& A.C. Marques. 2016. Variability on microevolutionary and macroevolutionary scales: a review on patterns of morphological variation in Cnidaria Medusozoa. Organisms Diversity \& Evolution 16: 431-442.

Dambach, J.; M.J. Raupach; F. Leese; J. Schwarzer \& J.O. Engler. 2016. Ocean currents determine functional connectivity in an Antarctic deep-sea shrimp. Marine Ecology 37: $1336-1344$.

Danovaro, R.; C. Corinaldesi; A. Dell'Anno \& P. Snelgrove. 2017. The deep-sea under global change. Current Biology 27: R461-R465.

De Groote, A.; F. Hauquier; A. Vanreusel \& S. Derycke. 2017. Population genetic structure in Sabatieria (Nematoda) reveals intermediary gene flow and admixture between distant cold seeps from the Mediterranean Sea. BMC Evolutionary Biology 17: 154.

Di Camillo, C.G.; F. Boero; C. Gravilli; M. Previati; F. Torsani \& C. Cerrano. 2013. Distribution, ecology and morphology of Lytocarpia myriophyllum (Cnidaria: Hydrozoa), a Mediterranean Sea habitat former to protect. Biodiversity \& Conservation 22: $772-787$.

Downey, R.V.; H.J. Griffiths; K. Linse \& D. Janussen. 2012. Diversity and distribution patterns in high southern latitude sponges. PLoS ONE 7: e41672.

Eilertsen, M.H. \& M.A.E. Malaquias. 2015. Speciation in the dark: diversification and biogeography of the deep-sea gastropod genus Scaphander in the Atlantic Ocean. Journal of Biogeography 42: 843-855. 
Etter, R.J. \& A.S. Bower. 2015. Dispersal and population connectivity in the deep North Atlantic estimated from physical transport processes. Deep-Sea Research I 104: 159172.

Etter, R.J. \& J.F. Grassle. 1992. Patterns of species diversity in the deep sea as a function of sediment particle size diversity. Nature 360: 576-78.

Everett, M.V.; L.K. Park; E.A. Berntson; A.E. Elz; C.E. Whitmire; A.A. Keller \& M.E. Clarke. 2016. Large-scale genotyping-by-sequencing indicates high levels of gene flow in the deep-sea octocoral Swiftia simplex (Nutting 1909) on the west coast of the United States. PLoS ONE 11: e0165279.

Fernandez, M.O. \& A.C. Marques. 2017a. Capítulo 1. Putting together bathymetry, latitude and phylogeny to understand the distribution of deep Atlantic hydroids (Cnidaria, Hydrozoa). In: Diversity of deep-sea Atlantic hydroids (Cnidaria) under a macroecological perspective. Dissertation. Universidade de São Paulo, São Paulo.

Fernandez, M.O. \& A.C. Marques. 2017b. Diversity of Diversities: A Response to Chaudhary, Saeedi, and Costello. Trends in Ecology \& Evolution 32: 232-234.

Fernandez, M.O.; A.G. Collins; A. Gittenberger \& A.C. Marques. 2017. Capítulo 2. Functional traits of hydroids (Cnidaria, Hydrozoa) vary with depth. In: Diversity of deep-sea Atlantic hydroids (Cnidaria) under a macroecological perspective. Dissertation. Universidade de São Paulo, São Paulo.

Fernandez, M.O.; S.A. Navarrete \& A.C. Marques. 2014. Temporal variation in richness and composition of recruits in a diverse cnidarian assemblage of subtropical Brazil. Journal of Experimental Marine Biology and Ecology 460: 144-152.

Fine, P.V.A. 2015. Ecological and evolutionary drivers of geographic variation in species diversity. Annual Review of Ecology, Evolution, and Systematics 46: 369-392.

Foell, E.J. \& D.L. Pawson. 1986. Photographs of invertebrate megafauna from abyssal depths of the north-eastern equatorial Pacific Ocean. Ohio Journal of Science 86: 61-68.

Gage, J.D. \& Tyler, P. A. 1991. Deep-Sea Biology: A Natural History of Organisms at the Deep-Sea Floor. Cambridge: Cambridge University Press.

Gallucci F.; E. Sauter; O. Sachs; M. Klages \& T. Soltwedel. 2008a. Caging experiment in the deep sea: efficiency and artefacts from a case study at the Arctic long-term observatory HAUSGARTEN. Journal of Experimental Marine Biology and Ecology, 354, 39-55.

Gallucci F.; G. Fonseca \& T. Soltwedel. 2008b. Effects of megafauna exclusion on nematode assemblages at a deep sea site. Deep Sea Research Part I: Oceanographic Research Papers, 55: 332-349. 
Gambi, C.; A. Vanreusel \& R. Danovaro. 2003. Biodiversity of nematode assemblages from deep-sea sediments of the Atacama Slope and Trench (South Pacific Ocean). Deep-Sea Research I 50: 103-117.

Gambi, C.; C. Corinaldesi; A. Dell'Anno; A. Pusceddu; G. D’Onghia; A. Covazzi-Harriague \& R. Danovaro. 2017. Global Ecology \& Biogeography DOI: 10.1111/geb.12608.

Gaston, K.J. 2000. Global patterns in biodiversity. Nature 405: 220-227.

Gaston, K.J. \& T.M. Blackburn. 2000. Patterns and process in macroecology. Blackwell Science, Oxford.

Gebruk, A.V.; P. Chevaldonné; T. Shank; R.A. Lutz \& R.C. Vrijenhoek. 2000. Deep-sea hydrothermal vent communities of the Logatchev area $\left(14^{\circ} 45^{\prime} \mathrm{N}\right.$, Mid-Atlantic Ridge): diverse biotopes and high biomass. Journal of the Marine Biological Association of the United Kingdom 80: 383-393.

Genin, A.; P.K. Dayton; P.F. Lonsdale \& F.N. Spiess. 1986. Corals on seamount peaks provide evidence of current acceleration over deep-sea topography. Nature 332: 59-61.

Genzano, G.N.; D. Giberto; L. Schejter; C. Bremec \& P. Meretta. 2009. Hydroid assemblages from the Southwestern Atlantic Ocean (34-42 S). Marine Ecology 30: 33-46.

Gibbons, M.J.; E. Buecher; D. Thibault-Botha \& R.R. Helm. 2010a. Patterns in marine hydrozoan richness and biogeography around southern Africa: implications of life cycle strategy. Journal of Biogeography 37: 606-616.

Gibbons, M.J.; L.A. Janson; A. Ismail \& T. Samaai. 2010b. Life cycle strategy, species richness and distribution in marine Hydrozoa (Cnidaria: Medusozoa). Journal of Biogeography 37: 441-448.

Gilbert, S.F. 2012. Ecological developmental biology: environmental signals for normal animal development. Evolution \& Development 14: 20-28.

Gili, J.M. \& R.G. Hughes. 1995. The ecology of marine benthic hydroids. Oceanography and Marine Biology: an Annual Review 33: 351-426.

Gollner, S.; Kaiser, S.; Menzel, L.; Jones, D.O.B.; Brown, A.; Mestre, N.C.; van Oevelen, D.; Menot, L.; Colaço, A.; Canals, M.; Cuvelier, D.; Durden, J.M.; Gebruk, A.; Egho, G.A.; Haeckel, M.; Marcon, Y.; Mevenkamp, L.; Morato, T.; Pham, C.K.; Purser, A.; Sanchez-Vidal, A.; Vanreusel, A.; Vink, A.; Arbizu, P.M. 2017. Resilience of benthic deep-sea fauna to mining activities. Marine Environmental Research doi: 10.1016/j.marenvres.2017.04.010.

Gooch, J.L. \& T.J.M. Schopf. 1972. Genetic variability in the deep-sea: relation to environmental variability. Evolution 26: 545-552. 
Gooday, A.J.; B.J. Bett; E. Escobar; B. Ingole; L.A. Levin; C. Neira; A.V. Raman \& J. Sellanes. 2010. Habitat heterogeneity and its influence on benthic biodiversity in oxygen minimum zones. Marine Ecology 31: 125-147.

Google. 2017. Google Earth. Available: http:/www.google.com/earth/. Accessed: February 2017.

Grantham, B.A.; G.L. Eckert \& A.L. Shanks. 2003. Dispersal potential of marine invertebrates in diverse habitats. Ecological Applications 13: S108-S116.

Gravier-Bonnet, N. 1992. Cloning and dispersal by buoyant autotomized hydrants of a thecate hydroid (Cnidaria; Hydrozoa). Scientia Marina 56: 229-236.

Hall, S. \& S. Thatje. 2009. Global bottlenecks in the distribution of marine Crustacea: temperature constraints in the family Lithodidae. Journal of Biogeography 36: 2125 2135.

Harley, C.D.G.; K.F. Smith \& V.L. Moore. 2003. Environmental variability and biogeography: the relationship between bathymetric distribution and geographical range size in marine algae and gastropods. Global Ecology \& Biogeography 12: 499-506.

Henry, L.-A.; M.S. Nizinski \& S.W. Ross. 2008. Occurrence and biogeography of hydroids (Cnidaria: Hydrozoa) from deep-water coral habitats off the southeastern United States. Deep-Sea Research I 55: 788-800.

Hessler, R.R. \& D. Thistle. 1975. On the place of origin of deep-sea isopods. Marine Biology 32: $155-165$.

Hessler, R.R. \& P.A. Jumars. 1974. Abyssal community analysis from replicate box cores in the central North Pacific. Deep-Sea Research 21: 185-209.

Hillebrand, H. 2004. Strength, slope and variability of marine latitudinal gradients. Marine Ecology Progress Series 273: 251-267.

Hughes, R.G. 1977. Aspects of the biology and life-history of Nemertesia antennina (L.) (Hydrozoa: Plumulariidae). Journal of the Marine Biological Association of the United Kingdom 57: 641-657.

Ingólfssson, O. 2004. Quaternary glacial and climate history of Antarctica. In: J. Ehlers \& P.L. Gibbard (Eds). Quaternary Glaciations - Extent and Chronology, Part III. Elsevier, Amsterdam.

Jablonski, D. \& D.J. Bottjer. 1991. Environmental patterns in the origins of higher taxa: the post-paleozoic fossil record. Science 252: 1831-1833.

Jablonski, D.; J.J. Sepkoski; D.J. Bottjer \& P.M. Sheehan. 1983. Onshore-offshore patterns in the evolution of phanerozoic shelf communities. Science 222: 1123-1125. 
Jablonski, D.; K. Roy \& J.W. Valentine. 2006. Out of the tropics: evolutionary dynamics of the latitudinal diversity gradient. Science 314: 102-106.

Jablonski, D.; K.W. Flessa \& J.W. Valentine. 1985. Biogeography and paleobiology. Paleobiology 11: 75-90.

Jamieson, A. 2015. The hadal zone: life in the deepest oceans. Cambridge University Press, New York.

Jones, D.O.B.; S. Kaiser; A.K. Sweetman; C.R. Smith; L. Menot; A. Vink; D. Trueblood; J. Greinert; D.S.M. Billett; P.M. Arbizu; T. Radziejewska; R. Singh; B. Ingole; T. Stratmann; E. Simon-Lledó; J.M. Durden; M.R. Clark. 2017. Biological responses to disturbance from simulated deep-sea polymetallic nodule mining. PLoS ONE 12: e0171750.

Judge, J. \& J.P. Barry. 2016. Macroinvertebrate community assembly on deep-sea wood falls in Monterey Bay is strongly influenced by wood type. Ecology 97: 3031-3043.

Keith, S.A.; T.J. Webb, K. Böhning-Gaese; S.R. Connolly; N.K. Dulvy; F. Eigenbrod; K.E. Jones; T. Price; D.W. Redding; I.P.F. Owens \& N.J.B. Isaac. 2012. What is macroecology? Biology Letters 8: 904-906.

Kramp, P.L. 1956. Hydroids from depths exceeding 6000 meters. Galathea Report 2: 17-20.

Kreft, H. \& W. Jetz. 2010. A framework for delineating biogeographical regions based on species distributions. Journal of Biogeography 37: 2029-2053.

Kussakin, O.G. 1973. Peculiarities of the geographical and vertical distribution of marine isopods and the problem of deep-sea fauna origin. Marine Biology 23: 19-34.

LaBella, A.L.; C.L. Van Dover; D. Jollivet \& C.W. Cunningham. 2017. Gene flow between Atlantic and Pacific Ocean basins in three lineages of deep-sea clams (Bivalvia: Vesicomyidae: Pliocardiinae) and subsequent limited gene flow within the Atlantic. Deep-Sea Research II 137: 307-317.

Lampitt, R.S. \& A.N. Antia. 1997. Particle flux in deep seas: regional characteristics and temporal variability. Deep-Sea Research I 44: 1377-1403.

Leclère, L.; P. Schuchert; M. Manuel. 2007. Phylogeny of the Plumularioidea (Hydrozoa, Leptothecata): evolution of colonial organisation and life cycle. Zoologica Scripta 36: 371-394.

Leprieur, F.; P. Descombes; T. Gaboriau; P.F. Cowman; V. Parravicini; M. Kulbicki; C.J. Melián; C.N. de Santana; C. Heine; D. Mouillot; D.R. Bellwood \& L. Pellissier. 2016. Plate tectonics drive tropical reef biodiversity dynamics. Nature Communications 7: 11461. 
Levin, L.A. \& A.J. Gooday. 2003. The deep Atlantic ocean. pp. 111-178. In: Ecosystems of the Deep Oceans. P.A. Tyler (Ed). Ecosystems of the World vol. 28, Elsevier Science, Amsterdam.

Levin, L.A.; A.R. Baco; D.A. Bowden; A. Colaco; E.E. Cordes; M.R. Cunha; A.W.J. Demopoulos; J. Gobin; B.M. Grupe; J. Le; A. Metaxas; A.N. Netburn; G.W. Rouse; A.R. Thurber; V. Tunnicliffe; C.L. Van Dover; A. Vanreusel \& L. Watling. 2016. Hydrothermal vents and methane seeps: rethinking the sphere of influence. Frontiers in Marine Science 3: 72.

Levin, L.A. \& J.D. Gage. 1998. Relationships between oxygen, organic matter and the diversity of bathyal macrofauna. Deep-Sea Research II 45: 129-163.

Levin, L.A.; R.J. Etter; M.A. Rex; A.J. Gooday; C.R. Smith; J. Pineda; C.T. Stuart; R.R. Hessler \& D. Pawson. 2001. Environmental influences on regional deep-sea species diversity. Annual Review of Ecology and Systematics 32: 51-93.

Lindner, A.; S.D. Cairns \& C.W. Cunningham. 2008. From offshore to onshore: multiple origins of shallow-water corals from deep-sea ancestors. PLoS ONE 3: e2429.

Lomolino, M.V.; B.R. Riddle \& R.J. Whittaker. 2017. Biogeography: biological diversity across space and time, 5th ed. Sinauer Associates, Inc., Sunderland, Massachusetts.

Louthan, A.M.; D.F. Doak \& A.L. Angert. 2015. Where and when do species interactions set range limits? Trends in Ecology \& Evolution 30: 780-792.

Madsen, F.J. 1961. On the zoogeography and origin of the abyssal fauna in view of the knowledge of the Porcellanasteridae. Galathea Report 4: 177-218.

Mangiafico, S. 2017. rcompanion: Functions to Support Extension Education Program Evaluation. $\mathrm{R}$ package version 1.5.6. Available: https://CRAN.Rproject.org/package=rcompanion.

Marfenin, N.N. 1997. Adaptation capabilities of marine modular organisms. Hydrobiologia 355: $153-158$.

Maronna, M.M.; T.P. Miranda; A.L. Peña Cantero; M.S. Barbeitos \& A.C. Marques. 2016. Towards a phylogenetic classification of Leptothecata (Cnidaria, Hydrozoa). Scientific Reports 6: 18075.

Marques, A.C. \& A.G. Collins. 2004. Cladistic analysis of Medusozoa and cnidarians evolution. Invertebrate Biology 123: 23-42.

Marques, A.C. \& A.L. Peña Cantero. 2010. Areas of endemism in the Antarctic - a case study of the benthic hydrozoan genus Oswaldella (Cnidaria, Kirchenpaueriidae). Journal of Biogeography 37: 617-623. 
Martín-Ledo, R. \& P.J. López-González. 2014. Brittle stars from Southern Ocean (Echinodermata: Ophiuroidea). Polar Biology 37: 73-88.

Matthysen, E. 2012. Multicausality of dispersal: a review. pp. 3-18. In: J. Clobert; M. Baguette; T.G. Benton \& J.M. Bullock (Eds). Dispersal Ecology and Evolution, Oxford University Press, Oxford.

McClain, C.R. 2004. Connecting species richness, abundance and body size in deep-sea gastropods. Global Ecology and Biogeography 13: 327-334.

McClain, C.R.; A.P. Allen; D.P. Tittensor \& M.A. Rex. 2012. Energetics of life on the deep seafloor. Proceedings of the National Academy of Sciences, USA 109: 15366-15371.

McClain, C.R.; J.C. Nekola; L. Kuhnz \& J.P. Barry. 2011. Local-scale faunal turnover on the deep Pacific seafloor. Marine Ecology Progress Series 422: 193-200.

McClain, C.R.; J.C. Stegen \& A.H. Hurlbert. 2012. Dispersal, environmental niches and oceanic-scale turnover in deep-sea bivalves. Proceedings of the Royal Society B 279: 1993-2002.

McClain, C.R. \& J.P. Barry. 2010. Habitat heterogeneity, disturbance, and productivity work in concert to regulate biodiversity in deep submarine canyons. Ecology 91: 964-976.

McClain, C.R.; M.A. Balk; M.C. Benfield; T.A. Branch; C. Chen; J. Cosgrove; A.D.M. Dove; L.C. Gaskins; R.R. Helm; F.G. Hochberg; F.B. Lee; A. Marshall; S.E. McMurray; C. Schanche; S.N. Stone \& A.D. Thaler. 2015. Sizing ocean giants: patterns of intraspecific size variation in marine megafauna. PeerJ 3: e715; DOI 10.7717/peerj.715.

McClain, C.R. \& M.A. Rex. 2015. Toward a conceptual understanding of $\beta$-diversity in the deep-sea benthos. Annual Review of Ecology, Evolution, and Systematics 46: 623-642.

McClain C.R.; M.A. Rex \& R.J. Etter. 2009. Patterns in deep-sea macroecology. pp. 65-100. In: J.D. Witman \& K. Roy (Eds). Marine macroecology, The University of Chicago Press, Chicago.

McClain, C.R.; M.A. Rex \& R. Jabbour. 2005. Deconstructing bathymetric body size patterns in deep-sea gastropods. Marine Ecology Progress Series 297: 181-187.

McClain, C.R. \& R.J. Etter. 2005. Mid-domain models as predictors of species diversity patterns: bathymetric diversity gradients in the deep sea. Oikos 109: 555-566.

McClain, C.R. \& S.M. Hardy. 2010. The dynamics of biogeographic ranges in the deep sea. Proceeding of the Royal Society B 277: 3533-3546.

Medel, M.D. \& W. Vervoort. 1998. Atlantic Thyroscyphidae and Sertulariidae (Hydrozoa, Cnidaria) collected during the CANCAP and Mauritania-II expeditions of the National 
Museum of Natural History, Leiden, The Netherlands. Zoologische Verhandelingen Leiden 320: 1-85.

Medel, M.D. \& W. Vervoort. 2000. Atlantic Haleciidae and Campanulariidae (Hydrozoa, Cnidaria) collected during the CANCAP and Mauritania-II expeditions of the National Museum of Natural History, Leiden, The Netherlands. Zoologische Verhandelingen Leiden 330: 1-68.

Mendoza Becerril, M.A. 2015. Padrões de diversificação de Bougainvilliidae no contexto evolutivo de Medusozoa (Cnidaria). Tese de doutorado. Instituto de Biociências, Universidade de São Paulo, 187p.

Mendoza-Becerril, M.A.; J.E.A.R. Marian; A.E. Migotto \& A.C. Marques. 2017. Exoskeletons of Bougainvilliidae and other Hydroidolina (Cnidaria, Hydrozoa): structure and composition. PeerJ 5: e2964; DOI 10.7717/peerj.2964.

Mendoza-Becerril, M.A.; M.M. Maronna; M.L.A.F. Pacheco; M.G. Simões; J.M. Leme; L.S. Miranda; A.C. Morandini \& A.C. Marques. 2016. An evolutionary comparative analysis of the medusozoan (Cnidaria) exoskeleton. Zoological Journal of the Linnean Society 178: 206-225.

Menzies, R.J.; R.Y. George \& G.T. Rowe. 1973. Abyssal environment and ecology of the world oceans. Wiley-Interscience, New York.

Mestre, N.C.; A. Brown \& S. Thatje. 2013. Temperature and pressure tolerance of larvae of Crepidula fornicata suggest thermal limitation of bathymetric range. Marine Biology 160: 743-750.

Micheli, F.; C.H. Peterson; L.S. Mullineaux; C.R. Fisher; S.W. Mills; G. Sancho; G.A. Johnson \& H.S. Lenihan. 2002. Predation structures communities at deep-sea hydrothermal vents. Ecological Monographs 72: 365-382.

Miglietta, M.P. \& C.W. Cunningham. 2012. Evolution of life cycle, colony morphology, and host specificity in the family Hydractiniidae (Hydrozoa, Cnidaria). Evolution 66: 3876 3901.

Migotto, A.E. \& A.C. Marques. 1999. Redescription of Dentitheca bidentata (Cnidaria: Hydrozoa, Plumulariidae), with notes on its life cycle. Journal of Natural History 33: 949-960.

Millard, N.A.H. 1975. Monograph on the Hydroida of southern Africa. Annals of the South African Museum 68: 1-513.

Millard, N.A.H. 1978. The geographical distribution of Southern African hydroids. Annals of the South African Museum 74: 159-200. 
Miranda, T.P.; G.N. Genzano \& A.C. Marques. 2015. Areas of endemism in the Southwestern Atlantic Ocean based on the distribution of benthic hydroids (Cnidaria: Hydrozoa). Zootaxa 4033: 484-506.

Mittelbach, G.G.; D.W. Schemske; H.V. Cornell; A.P. Allen; J.M. Brown; M.B. Bush; S.P. Harrison; A.H. Hurlbert; N. Knowlton; H.A. Lessios; C.M. McCain; A.R. McCune; L.A. McDade; M.A. McPeek; T.J. Near; T.D. Price; R.E. Ricklefs; K. Roy; D.F. Sax; D. Schluter; J.M. Sobel \& M. Turelli. 2007. Evolution and the latitudinal diversity gradient: speciation, extinction and biogeography. Ecology Letters 10: 315-331.

Moreau, C.; T. Saucède; Q. Jossart; A. Agüera; A. Brayard \& B. Danis. 2017. Reproductive strategy as a piece of the biogeographic puzzle: a case study using Antarctic sea stars (Echinodermata, Asteroidea). Journal of Biogeography 44: 848-860.

Morris, J.P.; S. Thatje; D. Cottin; A. Oliphant; A. Brown; B. Shillito; J. Ravaux \& C. Hauton. 2015. The potential for climate-driven bathymetric range shifts: sustained temperature and pressure exposures on a marine ectotherm, Palaemonetes varians. Royal Society open science 2: 150472 .

Morrone, J.J. 2009. Evolutionary Biogeography: an integrative approach with case studies. Columbia University Press, New York.

Moura, C.J.; D.J. Harris; M.R. Cunha; A.D. Rogers. 2008. DNA barcoding reveals cryptic diversity in marine hydroids (Cnidaria, Hydrozoa) from coastal and deep-sea environments. Zoologica Scripta 37: 93-108.

Nutting, C.C. 1900. American hydroids. Part I. The Plumularidae. Smithsonian Institution, United States National Museum Special Bulletin 4: 1-285.

Nutting, C.C. 1904. American hydroids. Part II. The Sertularidae. Smithsonian Institution, United States National Museum Special Bulletin 4: 1- 325.

Nutting, C.C. 1915. American hydroids. Part III. The Campanularidae and the Bonneviellidae. Smithsonian Institution, United States National Museum Special Bulletin 4: 1-126.

Oksanen, J.; F.G. Blanchet; M. Friendly; R. Kindt; P. Legendre; D. McGlinn; P.R. Minchin; R.B. O'Hara; G.L. Simpson; P. Solymos; M.H.H. Stevens; E. Szoecs \& H. Wagner. 2017. vegan: Community Ecology Package. R package version 2.4-4.

Olabarria, C. \& M.H. Thurston. 2003. Latitudinal and bathymetric trends in body size of the deep-sea gastropod Troschelia berniciensis (King). Marine Biology 143: 723-730.

Omori, M. \& W. Vervoort. 1986. Observations on a living specimen of the giant hydroid Branchiocerianthus imperator. Zoologische Mededelingen 60: 257-261. 
Peña Cantero, A.L. 2004. How rich is the deep-sea Antarctic benthic hydroid fauna? Polar Biology 27: 767-774.

Peña Cantero, A.L. 2008. Benthic hydroids (Cnidaria: Hydrozoa) from the Spanish Antarctic expedition Bentart 95. Polar Biology 31: 451-464.

Peña Cantero, A.L. \& A.M. García Carrascosa. 1999. Biogeographical distribution of the benthic thecate hydroids collected during the spanish "Antártida 8611" expedition and comparison between Antarctic and Magellan benthic hydroid faunas. Scientia Marina 63: 209-218.

Peña Cantero, A.L.; A. Svoboda \& W. Vervoort. 2004. Antarctic hydroids (Cnidaria, Hydrozoa) of the families Campanulinidae, Lafoeidae and Campanulariidae from recent Antarctic expeditions with R.V. Polarstern, with the description of a new species. Journal of Natural History 38: 2269-2303.

Peña Cantero, A.L.; E.R. Ferrer \& T.P. Miranda. 2017. Species of Antarctoscyphus Peña Cantero, García Carrascosa and Vervoort, 1997 (Cnidaria: Hydrozoa: Symplectoscyphidae) collected by US Antarctic expeditions: biogeographic implications. Journal of Natural History 51: 1437-1477.Peña Cantero, A.L. \& A.M. García Carrascosa. 1995. Hidrozoos bentónicos de la Campaña Antártida 8611. Publicaciones Especiales, Instituto Español de Oceanografía 19: 1-148.

Peña Cantero, A.L. \& F. Ramil. 2006. Benthic hydroids associated with volcanic structures from Bransfield Strait (Antarctica) collected by the Spanish Antarctic expedition GEBRAP96. Deep-Sea Research II 53: 949-958.

Peña Cantero, A.L. \& W. Vervoort. 2003. Species of Staurotheca Allman, 1888 (Cnidaria: Hydrozoa: Sertulariidae) from US Antarctic expeditions, with the description of three new species. Journal of Natural History 37: 2653-2722.

Peña Cantero, A.L. \& W. Vervoort. 2009. Benthic hydroids (Cnidaria: Hydrozoa) from the Bransfield Strait area (Antarctica) collected by Brazilian expeditions, with the description of a new species. Polar Biology 32: 83-92.

Peters, R.H. 1983. The ecological implications of body size. Cambridge University Press, Cambridge.

Piepenburg, D. 2005. Recent research on Arctic benthos: common notions need to be revised. Polar Biology 28: 733-755.

Pineda, J. 1993. Boundary effects on the vertical ranges of deep-sea benthic species. Deep-Sea Research I 40: 2179-2192. 
Pineda, J. \& H. Caswell. 1998. Bathymetric species-diversity patterns and boundary constraints on vertical range distributions. Deep-Sea Research II 45: 83-101.

Postaire, B.; P. Gélin; J.H. Bruggemann; M. Pratlong \& H. Magalon. 2017. Population differentiation or species formation across the Indian and the Pacific Oceans? An example from the brooding marine hydrozoan Macrorhynchia phoenicea. Ecology and Evolution 00: 1-17.

Poulin, E.; C. González-Wevar; A. Díaz; K. Gérard \& M. Hüne. 2014. Divergence between Antarctic and South American marine invertebrates: What molecular biology tells us about Scotia Arc geodynamics and the intensification of the Antarctic Circumpolar Current. Global and Planetary Change 123: 392-399.

Powell, M.G.; V.P. Beresford \& B.A. Colaianne. 2012. The latitudinal position of peak marine diversity in living and fossil biotas. Journal of Biogeography 39: 1687-1694.

Pradillon, F. \& F. Gaill. 2007. Pressure and life: some biological strategies. Reviews in Environmental Science and Biotechnology 6: 181-195.

Puig, P.; M. Canals; J.B. Company; J. Martín; D. Amblas; G. Lastras; A. Palanques \& A.M. Calafat. 2012. Ploughing the deep sea floor. Nature 489: 286-290.

R Core Team. 2017. R: A Language and Environment for Statistical Computing. R Foundation for Statistical Computing, Vienna, Austria (http://www.R-project.org/. Accessed in 05/07/2017).

Ramil, F. \& W. Vervoort. 1992. Report on the Hydroida collected by the "BALGIM" expedition in and around the Strait of Gibraltar. Zoologische Verhandelingen Leiden 277: $1-262$.

Ramil, F.; W. Vervoort \& J.A. Ansín. 1998. Report on the Haleciidae and Plumularioidea (Cnidaria, Hydrozoa) collected by the French SEAMOUNT 1 Expedition. Zoologische Verhandelingen Leiden 322: 1-42.

Ramirez-Llodra, E.; A. Brandt; R. Danovaro; B. De Mol; E. Escobar; C.R. German; L.A. Levin; P. Martinez Arbizu; L. Menot; P. Buhl-Mortensen; B.E. Narayanaswamy; C.R. Smith; D.P. Tittensor; P.A. Tyler; A. Vanreusel \& M. Vecchione. 2010. Deep, diverse and definitely different: unique attributes of the world's largest ecosystem. Biogeosciences 7: 2851-2899.

Ramirez-Llodra, E.; P.A. Tyler; M.C. Baker; O.A. Bergstad; M.R. Clark; E. Escobar; L.A. Levin; L. Menot; A.A. Rowden; C.R. Smith \& C.L. Van Dover. 2011. Man and the last great wilderness: human impact on the deep sea. PLoS ONE 6: e22588. 
Renema, W.; D.R. Bellwood; J.C. Braga; K. Bromfield; R. Hall; K.G. Johnson; P. Lunt; C.P. Meyer; L.B. McMonagle; R.J. Morley; A. O’Dea; J.A. Todd; F.P. Wesselingh; M.E. Wilson \& J.M. Pandolfi. 2008. Hopping hotspots: global shifts in marine biodiversity. Science 321: 654-657.

Rex, M.A. 1973. Deep-sea species diversity: decreased gastropod diversity at abyssal depths. Science 181: 1051-1053.

Rex, M.A. 1976: Biological accomodation in the deep-sea benthos- comparative evidence on the importance of predation and productivity. Deep Sea Research 23: 975-987.

Rex, M.A. 1977. Zonation in deep-sea gastropods: the importance of biological interactions to rates of zonation. European Symposium of Marine Biology 11: 521-530.

Rex, M.A. 1981. Community structure in the deep-sea benthos. Annual Review of Ecology and Systematics 12: 331-353.

Rex, M.A.; A. Crame; C.T. Stuart \& A. Clarke. 2005. Large-scale biogeographic patterns in marine mollusks: a confluence of history and productivity? Ecology 86: 2288-2297.

Rex, M.A.; C.R. McClain; N.A. Johnson; R.J. Etter; J.A. Allen; P. Bouchet \& A. Warén. 2005. A source-sink hypothesis for abyssal biodiversity. The American Naturalist 165: 163178.

Rex, M.A.; C.T. Stuart \& G. Coyne. 2000. Latitudinal gradients of species richness in the deepsea benthos of the North Atlantic. Proceedings of the National Academy of Sciences, USA 97: 4082-85.

Rex, M.A.; C.T. Stuart; R.J. Etter \& C.R. McClain. 2010. Biogeography of the deep-sea gastropod Oocorys sulcata Fischer 1884. Journal of Conchology 40: 287-290.

Rex, M.A.; C.T. Stuart; R.R. Hessler; J.A. Allen; H.L. Sanders \& G.D.F. Wilson. 1993. Globalscale latitudinal patterns of species diversity in the deep-sea benthos. Nature 365: 636639.

Rex, M.A \& R.J. Etter. 1998. Bathymetric patterns of body size: implications for deep-sea biodiversity. Deep-Sea Research II 45: 103-127.

Rex, M.A. \& R.J. Etter. 2010. Deep-sea biodiversity: pattern and scale. Harvard University Press, Cambridge.

Rex, M.A.; R.J. Etter; J.S. Morris; J. Crouse; C.R. McClain; N.A. Johnson; C.T. Stuart; J.W. Deming; R. Thies \& R. Avery. 2006. Global bathymetric patterns of standing stock and body size in the deep-sea benthos. Marine Ecology Progress Series 317: 1-8. 
Rodriguez, C.S.; A.C. Marques; H.W. Mianzan; V.B. Tronolone; A.E. Migotto \& G.N. Genzano. 2017. Environment and life cycles influence distribution patterns of hydromedusae in austral South America. Marine Biology Research 13: 659-670.

Ronowicz, M.; P. Kuklinski \& G.M. Mapstone. 2015. Trends in the diversity, distribution and life history strategy of Arctic Hydrozoa (Cnidaria). PLoS ONE 10: e0120204.

Sanders, H.L. 1968. Marine benthic diversity: a comparative study. American Naturalist 102: $243-282$.

Sanders, H.L. \& R.R. Hessler. 1969. Ecology of deep-sea benthos. Science 163: 1419-1424.

Schuchert, P. 2000. Hydrozoa (Cnidaria) of Iceland collected by the BIOICE programme. Sarsia 85: 411-438.

Schuchert, P. 2012. North-west European athecate hydroids and their medusae. Synopses of the British Fauna, New Series 59: 1-364.

Schuchert, P. 2014. High genetic diversity in the hydroid Plumularia setacea: A multitude of cryptic species or extensive population subdivision? Molecular Phylogenetics and Evolution 76: 1-9.

Sexton, J.P.; P.J. McIntyre; A.L. Angert \& K.J. Rice. 2009. Evolution and ecology of species range limits. Annual Review of Ecology, Evolution, and Systematics 40: 415-436.

Smith, A.B. \& B. Stockley. 2005. The geological history of deep-sea colonization by echinoids: roles of surface productivity and deep-water ventilation. Proceedings of the Royal Society B 272: 865-869.

Smith, C.R.; F.C. De Leo; A.F. Bernardino; A.K. Sweetman \& P.M. Arbizu. 2008. Abyssal food limitation, ecosystem structure and climate change. Trends in Ecology \& Evolution 23: 518-528.

Smith, C.R.; W. Berelson; D.J. Demaster; F.C. Dobbs; D. Hammond; D.J. Hoover; R.H. Pope \& M. Stephens. 1997. Latitudinal variations in benthic processes in the abyssal equatorial Pacific: control by biogenic particle flux. Deep Sea Research II 44: 22952317.

Smith, K.E. \& S. Thatje. 2012. The Secret to successful deep-sea invasion: does low temperature hold the key? PLoS ONE 7: e51219.

Smith, S.I. \& O. Harger. 1874. Report on the dredgings in the region of St. George's Banks, in 1872. Transactions of the Connecticut Academy of Arts and Sciences 3: 1-57.

Soininen, J.; A. Jamoneau; J. Rosebery \& S.I. Passy. 2016. Global patterns and drivers of species and trait composition in diatoms. Global Ecology and Biogeography 25: 940950. 
Soininen, J.; J.J. Lennon \& H. Hillebrand. 2007a. A multivariate analysis of beta diversity across organisms and environments. Ecology 88: 2830-2838.

Soininen, J.; R. McDonald \& H. Hillebrand. 2007b. The distance decay of similarity in ecological communities. Ecography 30: 3-12.

Somero, G.N. 1990. Life at low volume change: hydrostatic pressure as a selective factor in the aquatic environment. American Zoologist 30: 123-135.

Somero, G.N. 1992. Adaptations to high hydrostatic pressure. Annual Review of Physiology 54: $557-577$.

Stearns, S.C. 1989. Trade-offs in life-history evolution. Functional Ecology 3: 259-268.

Stepanjants, S.D. 1989. Hydrozoa of the Eurasian Arctic Seas. pp. 397-430. In: The Arctic Seas Climatology, Oceanography, and Biology. Y. Herman (Ed). Van Nostrand Reinhold Company, New York.

Stepanjants, S.D. \& A.V. Chernyshev. 2015. Deep-sea epibiotic hydroids from the abyssal plain adjacent to the Kuril-Kamchatka Trench with description of Garveia belyaevi sp. nov. (Hydrozoa, Bougainvilliidae). Deep-Sea Research II 111: 44-48.

Stevenson, A.; F.J.G. Mitchell \& J.S. Davies. 2015. Predation has no competition: factors influencing space and resource use by echinoids in deep-sea coral habitats, as evidenced by continuous video transects. Marine Ecology 36: 1454-1467.

Stewart, R.H. 2006. Introduction to Physical Oceanography. Texas A \& M University.

Stillman, J.H. \& G.N. Somero. 2000. A comparative analysis of the upper thermal tolerance limits of eastern Pacific porcelain crabs, genus Petrolisthes: influences of latitude, vertical zonation, acclimation, and phylogeny. Physiological and Biochemical Zoology 73: 200-208.

Stuart, C.T.; S. Brault; G.T. Rowe; C.-L. Wei; M. Wagstaff; C.R. McClain \& M.A. Rex. 2017. Nestedness and species replacement along bathymetric gradients in the deep sea reflect productivity: a test with polychaete assemblages in the oligotrophic north-west Gulf of Mexico. Journal of Biogeography 44: 548-555.

Sweetman, A.K.; A.R. Thurber; C.R. Smith; L.A. Levin; C. Mora; C.-L. Wei; A.J. Gooday; D.O.B. Jones; M. Rex; M. Yasuhara; J. Ingels; H.A. Ruhl; C.A. Frieder; R. Danovaro; L. Würzberg; A. Baco; B.M. Grupe; A. Pasulka; K.S. Meyer; K.M. Dunlop; L.-A. Henry \& J.M. Roberts. 2017. Major impacts of climate change on deep-sea benthic ecosystems. Elementa Science of the Anthropocene 5: 4.

Talley, L.D.; G.L. Pickard; W.J. Emery; J.H. Swift. 2011. Descriptive Physical Oceanography: An Introduction (Sixth Edition). Elsevier, Boston. 
Teixeira, S.; K. Olu; C. Decker; R.L. Cunha; S. Fuchs; S. Hourdez; E.A. Serrão \& S. ArnaudHaond. 2013. High connectivity across the fragmented chemosynthetic ecosystems of the deep Atlantic Equatorial Belt: efficient dispersal mechanisms or questionable endemism? Molecular Ecology 22: 4663-4680.

Thatje, S.; C.-D. Hillenbrand; A. Mackensen \& R. Larter. 2008. Life hung by a thread: endurance of Antarctic fauna in glacial periods. Ecology 89: 682-692.

Thatje, S.; C.-D. Hillenbrand \& R. Larter. 2005. On the origin of Antarctic marine benthic community structure. Trends in Ecology and Evolution 20: 534-540.

Thiel, H. 1979. Structural aspects of the deep-sea benthos. Ambio 6: 25-31.

Thistle D.; J.E. Eckman \& G.L. Paterson. 2008. Large, motile epifauna interact strongly with harpacticoid copepods and polychaetes at a bathyal site. Deep Sea Research Part I: Oceanographic Research Papers 55: 324-331.

Thomson, M.R.A. 2004. Geological and palaeoenvironmental history of the Scotia Sea region as a basis for biological interpretation. Deep-Sea Research II 51: 1467-1487.

Tittensor, D.P.; C. Mora; W. Jetz; H.K. Lotze; D. Ricard; E.V. Berghe \& B. Worm. 2010. Global patterns and predictors of marine biodiversity across taxa. Nature 466: 10981101.

Tökölyi, J.; F. Bradács; N. Hóka; N. Kozma; M. Miklós; O. Mucza; K. Lénárt; Z. Ösz; F. Sebestyén \& Z. Barta. 2016. Effects of food availability on asexual reproduction and stress tolerance along the fast-slow life history continuum in freshwater hydra (Cnidaria: Hydrozoa). Hydrobiologia 766: 121-133.

Tyler P.A. \& C.M. Young. 1998. Temperature and pressure tolerances in dispersal stages of the genus Echinus (Echinodermata: Echinoldea): prerequisites for deep-sea invasion and speciation. Deep-Sea Research II 45: 253-277.

Tyler, P.A.; C.M. Young \& A. Clarke. 2000. Temperature and pressure tolerances of embryos and larvae of the Antarctic sea urchin Sterechinus neumayeri (Echinodermata: Echinoidea): potential for deep-sea invasion from high latitudes. Marine Ecology Progress Series 192: 173-180.

UNESCO. 2009. Global Open Oceans and Deep Seabed (GOODS) - Biogeographic Classification. IOC Technical Series, 84. UNESCO-IOC, Paris.

Usseglio-Polatera, P.; M. Bournaud; P. Richoux \& H. Tachet. 2000. Biological and ecological traits of benthic freshwater macroinvertebrates: relationships and definition of groups with similar traits. Freshwater Biology 43: 175-205. 
Valentine, J.W. 1973. Evolutionary paleoecology of the marine biosphere. Prentice-Hall, Inc., New Jersey.

van der Grient, J.M.A. \& A.D. Rogers. 2015. Body size versus depth: regional and taxonomical variation in deep-sea meio- and macrofaunal organisms. pp. 71-108. In: B.E. Curry (Ed). Advances in marine biology, Vol 71, Academic Press, Oxford.

Van Dover, C.L.; C.R. German; K.G. Speer; L.M. Parson \& R.C. Vrijenhoek. 2002. Evolution and biogeography of deep-sea vent and seep invertebrates. Science 295: 1253-1257.

Van Iten, H.; A.C. Marques; J.M. Leme; M.L.A.F. Pacheco \& M.G. Simões. 2014. Origin and early diversification of the phylum Cnidaria Verrill: major developments in the analysis of the taxon's Proterozoic-Cambrian history. Palaeontology 57: 677-690.

Vanreusel, A.; A. Hilario; P.A. Ribeiro; L. Menot \& P.M. Arbizu. 2016. Threatened by mining, polymetallic nodules are required to preserve abyssal epifauna. Scientific Reports 6: 26808.

Vanreusel, A.; G. Fonseca; R. Danovaro; M.C. Silva; A.M. Esteves; T. Ferrero; G. Gad; V. Galtsova; C. Gambi; V.F. Genevois; J. Ingels; B. Ingole; N. Lampadariou; B. Merckx; D. Miljutin; M. Miljutina; A. Muthumbi; S. Netto; D. Portnova; T. Radziejewska; M. Raes; A. Tchesunov; J. Vanaverbeke; S. Van Gaever; V. Venekey; T.N. Bezerra; H. Flint; J. Copley; E. Pape; D. Zeppilli; P.A. Martinez \& J. Galeron. 2010. The contribution of deep-sea macrohabitat heterogeneity to global nematode diversity. Marine Ecology 31: 6-20.

Verrill, A.E. 1874. Results of recent dredging expeditions on the coast of New England. American Journal of Science and Arts 7: 38-46; 7: 131-138; 7: 405-414; 7: 498-505.

Vervoort, W. 1966. Bathyal and abyssal hydroids. Galathea Report 8: 97-174.

Vervoort, W. 2006. Leptolida (Cnidaria: Hydrozoa) collected during the CANCAP and Mauritania-II expeditions of the National Museum of Natural History, Leiden, The Netherlands [Anthoathecata, various families of Leptothecata and addenda]. Zoologische Mededelingen 80: 181-318.

Vinogradova, N.G. 1979. The geographical distribution of the abyssal and hadal (ultra-abyssal) fauna in relation to the vertical zonation of the ocean. Sarsia 64: 41-50.

Vinogradova, N.G. 1997. Zoogeography of the abyssal and hadal zones. Advances in Marine Biology 32: 325-387.

Violle, C.; M.L Navas; D. Vile; E. Kazakou; C. Fortunel; I. Hummel \& E. Garnier. 2007. Let the concept of trait be functional! Oikos 116: 882-892. 
Vrijenhoek, R.C. 2010. Genetic diversity and connectivity of deep-sea hydrothermal vent metapopulations. Molecular Ecology 19: 4391-4411.

Watling, L.; J. Guinotte; M.R. Clark \& C.R. Smith. 2013. A proposed biogeography of the deep ocean floor. Progress in Oceanography 111: 91-112.

Watson, J.E. 2017. Two bathyal hydroids (Hydrozoa: Leptothecata) from the Southwest Indian Ocean. Zootaxa 4247: 336-340.

Webb, T.J.; E.H.M. Tyler \& P.J. Somerfield. 2009. Life history mediates large-scale population ecology in marine benthic taxa. Marine Ecology Progress Series 396: 293-306.

Wei, C.-L.; G.T. Rowe; G.F. Hubbard; A.H. Scheltema; G.D.F. Wilson; I. Petrescu; J.M. Foster; M.K. Wicksten; M. Chen; R. Davenport; Y. Soliman \& Y. Wang. 2010. Bathymetric zonation of deep-sea macrofauna in relation to export of surface phytoplankton production. Marine Ecology Progress Series 399: 1-14.

Weill, R. 1934. Contribution a l'étude des cnidaires et de leurs nématocystes. I, II. Travaux de la Station Zoologique de Wimereux 10: 1-701.

Wheeler, B. \& M. Torchiano. 2016. 1mPerm: Permutation Tests for Linear Models. R package version 2.1.0. Available: http://CRAN.R-project.org/package=lmPerm.

Whitaker, D. \& M. Christman. 2014. clustsig: Significant Cluster Analysis. R package version 1.1 .

Winston, J.E. 2012. Dispersal in marine organisms without a pelagic larval phase. Integrative and Comparative Biology 52: 447-457.

Witman, J.D. \& K. Roy. 2009. Marine macroecology. The University of Chicago Press, Chicago.

Won, Y.; C.R. Young; R.A. Lutz \& R.C. Vrijenhoek. 2003 Dispersal barriers and isolation among deep-sea mussel populations (Mytilidae: Bathymodiolus) from eastern Pacific hydrothermal vents. Molecular Ecology 12: 169-184.

Woolley, S.N.C.; D.P. Tittensor; P.K. Dunstan; G. Guillera-Arroita; J.J. Lahoz-Monfort; B.A. Wintle; B. Worm \& T.D. O’Hara. 2016. Deep-sea diversity patterns are shaped by energy availability. Nature 533: 393-396.

WoRMS Editorial Board. 2017. World Register of Marine Species. Available: http://www.marinespecies.org. Accessed: August 2017.

Young, C.M.; M.A. Sewell; P.A. Tyler \& A. Metaxas. 1997a. Biogeographic and bathymetric ranges of Atlantic deep-sea echinoderms and ascidians: the role of larval dispersal. Biodiversity and Conservation 6: 1507-1522. 
Young, C.M.; P.A. Tyler \& L. Fenaux. 1997b. Potential for deep-sea invasion by Meditteranean shallow-water echinoids: pressure and temperature as stage-specific dispersal barriers. Marine Ecology Progress Series 154: 197-209.

Zaffos, A.; S. Finnegan \& S.E. Peters. 2017. Plate tectonic regulation of global marine animal diversity. Proceedings of the National Academy of Sciences 114: 5653-5658.

Zeppilli, D.; L. Bongiorni; R.S. Santos \& A. Vanreusel. 2014. Changes in nematode communities in different physiographic sites of the condor seamount (north-east Atlantic Ocean) and adjacent sediments. PLoS ONE 9: e115601.

Zezina, O.N. 1997. Biogeography of the bathyal zone. Advances in Marine Biology 32: 389426.

Zhou, K.; L. Zheng; J. He; Y. Lin; W. Cao \& W. Zhang. 2013. Detection of a new Clytia species (Cnidaria: Hydrozoa: Campanulariidae) with DNA barcoding and life cycle analyses. Journal of the Marine Biological Association of the United Kingdom 93: 2075-2088. 